\title{
The impact of Populist Radical Right Parties on socio-economic policies
}

\author{
LEONCE RÖTH ${ }^{1}$, ALEXANDRE AFONSO ${ }^{2}$ AND DENNIS C. SPIES ${ }^{1}$ * \\ ${ }^{1}$ Cologne Center for Comparative Politics, University of Cologne, Köln, Germany \\ ${ }^{2}$ Institute of Public Administration - Campus den Haag, Leiden University, The Hague, The Netherlands
}

\begin{abstract}
Because they are now members of most Western European parliaments, Populist Radical Right Parties (PRRPs) have the potential to influence the formulation of socio-economic policies. However, scholarly attention so far has nearly exclusively focussed on the impact of PRRPs on what is considered their 'core issue', that is migration policy. In this paper, we provide the first mixed methods comparative study of the impact of PRRPs on redistributive and (de-)regulative economic policies. Combining quantitative data with qualitative case studies, our results show that the participation of PRRPs in right-wing governments has noteworthy implications for socio-economic policies. Due to the heterogeneous constituencies of PRRPs, these parties not only refrain from welfare state retrenchment but are also less inclined to engage in deregulation compared with right-wing governments without PRRP participation.
\end{abstract}

Keywords: Populist Radical Right Parties; social spending; economic liberalization; Western Europe

\section{Introduction}

Populist Radical Right Parties (PRRPs) have successfully evolved from 'pariahs to power' (De Lange, 2008). At first ostracized by other parties, they are now represented in the parliaments of most Western European countries, have taken part in government in a number of them, and therefore influence policymaking. Accordingly, scholarly attention has slowly started to move its focus from explaining their electoral fortunes to analysing their impact on public policies (Akkerman and De Lange, 2012; De Lange, 2012).

With a few exceptions (e.g. Verbeek and Zaslove, 2015), however, previous studies have so far mostly focussed on the impact of PRRPs on policies within their 'core domains', such as migration and integration policy (e.g. Akkerman, 2012). However, achieving parliamentary or executive representation also gives PRRPs potential influence in other core areas of state intervention, including economic and social policies. This article offers the first systematic comparative study of their impact on both redistributive (i.e. social spending and welfare generosity) and regulative (i.e. market-making) economic policies in Western Europe.

In order to analyse the impact of PRRPs on socio-economic policies, we combine quantitative and qualitative methods (Lieberman, 2005). We first address the

*E-mail: spies@wiso.uni-koeln.de 
impact of the parliamentary representation of PRRPs and their government participation on socio-economic policy formulation between 1970 and 2010 in 17 West European countries. Using a matching tool for case selection, we complement our statistical analysis with a case study of PRRP government participation in Austria in the 1990s and 2000s in order to gather insights into the policy-making processes at work.

\section{PRRPs and socio-economic policy}

The last three decades have witnessed the strengthening and 'mainstreaming' of PRRPs within West European party systems (Mudde, 2007). While the electoral fortunes of parties within this family vary greatly, many have managed to establish themselves as relevant actors in government coalitions in countries such as Austria, the Netherlands, Switzerland, Norway, and Italy. As their electoral success hinged on stricter immigration controls, tougher law and order policies, and restrictive welfare provision for immigrants in particular (Van der Brug and Fennema, 2003; Betz and Johnson, 2004; Mudde, 2007), it has naturally raised the question of their impact on policy formulation (see Mudde, 2013 for a recent review).

Previous studies have understandably focussed on the impact of PRRPs on the policy domains that they are considered to 'own', such as immigration, integration, and law and order (Minkenberg, 2001; Zaslove, 2004; Bale, 2008; Akkerman, 2012; Mudde, 2013). Indeed, research has shown that these parties mobilize voters primarily along the value/identity dimension and not so much on the socio-economic dimension of electoral politics (Gabel and Huber, 2000; Arzheimer and Carter, 2003; Kriesi et al., 2006; Van der Brug and Van Spanje, 2009). However, this does not mean that they cannot affect socio-economic policies, especially as coalition politics involves complex negotiations about different policy issues with other parties. Yet, no systematic large- $N$ analysis has been conducted on the socio-economic policy impact of PRRPs and the number of qualitative case studies explicitly addressing this question is limited (see, however, Afonso, 2015; Afonso and Papadopoulos, 2015). This is somewhat surprising because the role and preferences of PRRPs in the socio-economic domain have been the subjects of sharp controversies, depending on the alleged preferences of their voters (vote-seeking strategies) and the autonomy of PRRP party elites towards them when it comes to coalition formation (office-seeking strategies).

\section{Vote-seeking strategies}

The first comparative studies in the field already pointed out that the Radical Right was not only interested in culturally related issues, but also in socio-economic questions as a result of the realignment of the economic preferences of workingclass voters towards pro-market agendas. One of the most prominent advocates of this view was Kitschelt (1995), who argued that the electoral success of PRRPs 
hinged on a combination of nationalism and neoliberalism (see also Betz, 1994). According to Kitschelt, PRRPs were indeed radical with regard to their culturally authoritarian stance, but also in their demand for laissez-faire policies aiming at less redistribution, lower taxation, and reduced welfare expenditures. They supported the deregulation of state monopolies and the dismantlement of neo-corporatist arrangements perceived to benefit the political establishment. Following this view, we would then expect PRRPs to support measures of liberalization once in government.

In recent studies, the market-liberal character of PRRPs has been questioned, especially by those interested in the political attitudes of PRRP voters. These studies convincingly show that PRRP supporters share similar concerns about cultural identity and especially immigration control (Van der Brug and Fennema, 2007; Arzheimer and Carter, 2009; Van der Brug and Van Spanje, 2009) but are profoundly divided in their socio-economic preferences. This divide exists in particular between their two traditional core clienteles, the anti-state petite bourgeoisie on the one hand and the traditionally left-leaning working class on the other (Ignazi, 2003; Ivarsflaten, 2005; Mudde, 2007; Spies, 2013; Afonso and Rennwald, 2017). In the face of these divisions, PRRPs are believed to follow strategies of 'position blurring', either presenting 'vague or contradictory positions' (Rovny, 2013: 6) or downplaying their socio-economic programme (Cole, 2005; Spies and Franzmann, 2011; Afonso, 2015), which some authors see as essentially subordinate to their nationalist ideology (Mudde, 2007: 119). However, such electoral strategies are of limited value once PRWPs are in office because their position on these matters becomes much more difficult to obscure, when laws have to be voted and budgets allocated. Then, strategies of position blurring might translate into inconsistent socio-economic policy reforms, for example, by mixing up general liberalization with 'specific (often purely symbolic) protectionist measures and new programmes for selected groups (small business owners, families with children and so on) deemed vital to the political success of the government" (Heinisch, 2003: 103).

Finally, different expectations of the policy impact of PRRPs appear in several studies where PRRPs are presented as new working-class parties (Ignazi, 2003; Arzheimer, 2012). These studies either show that working-class voters are already the most important group in PRRPs or claim that working-class support for the Radical Right is steadily increasing (Betz, 2002; Spies, 2013; Afonso and Rennwald, 2017). The common inference from these electoral changes is that PRRPs have abandoned their former market-liberal positions in favour of more centrist agendas, in line with the preferences of their now more left-leaning supporters (Kitschelt, 2004; McGann and Kitschelt, 2005; De Lange, 2007; Kitschelt, 2007; Van Spanje and Van der Brug, 2007; Aichholzer et al., 2014; Schumacher and Kersbergen, 2014). This re-orientation of PRRPs should express itself especially with regard to redistributive social policies as the working-class still has a strong interest in the preservation of traditional social insurance schemes (Häusermann et al., 2013: 229; Afonso, 2015). 
Summarizing the arguments on the policy preferences of PRRPs derived from their electoral constituencies, the theoretical expectations are mixed. On the one hand, even the initial advocates of the 'winning formula' (Kitschelt, 2004; McGann and Kitschelt, 2005; Kitschelt, 2007) acknowledge that the socio-economic profile of PRRP voters today is much more left-leaning than in the early 1990s. On the other hand, PRRPs do not seem to follow a clear socio-economic agenda and the salience of these issues in their programmes remains low. Their policy stance is therefore unclear both during electoral campaigns, when they try to diffuse their positions, and in government, when they seem to advocate somewhat inconsistent political platforms.

\section{Office-seeking strategies}

So far, we have derived our arguments on the policy impact of PRRPs from the socio-economic profile of their voters. However, as far as Western Europe is concerned, PRRPs have been able to enter national government coalitions only with other right-wing (Conservative, Christian-democratic, or Liberal) political parties generally holding market-liberal views on the economy. ${ }^{1}$ The participation of these parties in government is hence embedded in intricate processes of coalition formation and logrolling with centre-right parties. According to De Lange (2012: 907), right-wing coalitions are an attractive option for mainstream right parties because PRRPs enable them to form politically viable and ideologically cohesive coalitions. As far as the mainstream right is concerned, political deals with PRRPs can draw on giving them concessions in the domain of immigration control (which PRRPs 'own' and on which mainstream right parties have converged anyway) in exchange for their support for liberalizing socio-economic reforms (which are more important for mainstream right parties than for PRRPs). This kind of political deal, however, may be dangerous for PRRPs if one considers their strong working-class base. Indeed, cutting welfare programmes on which many of their voters rely can translate into severe electoral losses. How can this trade-off be resolved?

We argue that this is possible only by differentiating socio-economic policies between those concerning redistribution (welfare state retrenchment being the most prominent among these) and those concerning the deregulation of former regulated markets, including financial liberalization, privatization of former state-owned companies, and the labour market (see Lowi, 1972; Aranson and Ordeshook, 1981). While their mainstream right coalition partners generally have a strong interest in both kinds of liberalization (see Bale, 2003; Giger and Nelson, 2011), we argue that PRRPs might have incentives to support (or consent to) deregulation but are more hesitant to support policies of welfare retrenchment once in government.

\footnotetext{
${ }^{1}$ One exception is the Syriza-Independent Greeks coalition formed in Greece in 2015, and Swiss governments where the radical right shares office with all major parties. The radical right has also held office with left-wing parties at the sub-national level in a number of countries.
} 
Starting with redistribution, supporting welfare retrenchment might be a serious problem for PRRPs because at least part of their electoral base has a strong interest in traditional social insurance programmes, such as pensions (Häusermann et al., 2013: 229; Afonso, 2015). Welfare reforms can be expected to be salient issues, and strategies of position blurring which can be successful during electoral campaigns are very difficult to carry out when in government. Thus, PRRPs face a potential trade-off between office and votes when it comes to redistribution (Afonso, 2015): supporting the policies of their liberal and conservative coalition partners may harm their own working-class electorate, while defending the interests of their own electorate may jeopardize alliances with their mainstream right partners. If PRRPs focus on votes, they should be more likely to defend the status quo when it comes to redistribution:

HYPOTHESIS 1: Centre-right governments with PRRP participation will pursue more redistributive economic policies compared with centre-right governments without PRRP participation.

As far as deregulation is concerned, we argue that the picture is different than this for redistributive issues, and that this domain is less problematic in terms of coalition bargaining and electoral effects. We see three main reasons for this. The most straightforward can be found in the interests of their potential mainstream right coalition partners. If PRRPs demand tougher immigration legislation but do not consent to welfare retrenchment, deregulation in other less salient domains becomes the only concession which can be offered.

Besides this coalition-based logic, PRRPs themselves might have a direct interest in deregulation given their general hostility to organized interests, especially to trade unions. This widespread critique of neo-corporatism among PRRPs is rooted in their anti-elite ideology (see Heinisch, 2003; Mudde, 2007). PRRPs as 'outsider' political actors may also favour deregulation because they have not been part of the state-market networks (including connections between parties, trade unions, and employers) that have governed many European market economies. Therefore, policies that might break up these corporatist networks and undermine the power of interest groups and established parties can be expected to find PRRP support. Trade unions, in particular, are among the most purposeful defenders of regulation (Davidsson and Emmenegger, 2013) because both labour market deregulation and privatization of formerly state-owned enterprises directly concern their own power base (Obinger et al., 2014). Hence, the deregulation of these domains should be in the direct interest of both PRRPs as well as pro-business mainstream right parties.

Finally, PRRPs might prefer deregulation to retrenchment because it is surely less salient in the eyes of their voters. Deregulation often appears rather technical and usually demands a higher degree of information to assess its outcomes, making such policies less conflictual in electoral terms than policies with clearer distributional effects. Therefore, support for deregulation might be more compatible with PRRPs' electoral strategy of 'position blurring'. Taking the three arguments together, we 
expect PRRPs in government to support policies of deregulation, or at least to consent to such reforms introduced by their centre-right coalition partners:

HYPOTHESIS 2: Governments with PRRP participation will support deregulatory economic policies. This results in deregulatory economic policies comparable to these of centre-right governments without PRRP participation.

Finally, the potential policy impact of PRRPs does not only hinge on their conflict between vote- or office-seeking strategies but also on the opportunity structures they face once in government. This involves, for instance, cabinet duration and the size of cabinet majorities. While the lack of adequate majorities and of sufficient time for the implementation of reforms are restrictions for any kind of government - be it with or without PRRP participation - for the analysis of PRRPs this argument is arguably even more important. Empirically, governments with PRRP participation tend to be less stable, and are significantly shorter than other governments. They might therefore simply lack the time to implement either redistributive or deregulatory reforms. To account for this, we will compare their policy impact depending on government duration and expect for both Hypotheses 1 and 2 that PRRP governments will have the most pronounced impact in the long run.

\section{Research design, method, and data}

To investigate our hypotheses, we combine a statistical analysis with case study evidence. We first conduct a large- $N$ quantitative analysis investigating the average effect of PRRP government participation on redistributive and regulative economic policies. In a second step, we quantitatively compare the impact of governments with PRRP support with comparable market-liberal governments depending on how much time the respective governments had to implement redistributive and deregulative reforms. Third, we select two cases (one with and one without a PRRP in cabinet), based on the distribution of the statistically most important variables. This within-case comparison provides us with evidence to establish the inference from the statistical analysis and weakens the power of alternative explanations.

We start by calculating several time-series cross-sectional regression models. In the first series, we analyse PRRPs' impact on welfare generosity. ${ }^{2}$ In the second part, we estimate their impact on deregulative economic policies. All models are based on data for 17 Western European countries ${ }^{3}$ for the period

\footnotetext{
${ }^{2}$ In addition, we also report models with welfare spending as the dependent variable in the Online Appendix of this paper (see Table C). In essence, these models show very comparable effects on the impact of PRRPs on welfare generosity.

3 These are: Austria, Belgium, Denmark, Finland, France, Germany, Greece, Ireland, Italy, Luxembourg, the Netherlands, Norway, Portugal, Spain, Sweden, Switzerland, and United Kingdom.
} 
Table 1. Populist Radical Right Parties (PRRPs) in government from 1970 to 2010

\begin{tabular}{|c|c|c|c|}
\hline Country & PRRP & Government participation (formal or informal) & Duration \\
\hline \multirow[t]{4}{*}{ Austria } & \multirow{3}{*}{$\begin{array}{l}\text { Freedom Party (since } \\
1986 \text { PRRP) }\end{array}$} & Formal: 04.02.2000-24.11.2002 (Schüssel I) & 1 \\
\hline & & 24.11.2002-28.02.2003 (Schüssel II) & 1 \\
\hline & & 28.02.2003-05.04.2005 (Schüssel III) & 1 \\
\hline & $\begin{array}{l}\text { Alliance for the Future } \\
\text { of Austria (BZö) }\end{array}$ & Formal: 05.04.2005-11.01.2007 (Schüssel IV) & 0 \\
\hline \multirow[t]{4}{*}{ Denmark } & \multirow[t]{4}{*}{ Danish People’s Party } & Informal: 27.11.2001-18.02.2005 (Rasmussen F I) & 2 \\
\hline & & 18.02.2005-23.11.2007 (Rasmussen F II) & 1 \\
\hline & & 23.11.2007-05.04.2009 (Rasmussen F III) & 1 \\
\hline & & 05.04.2009-02.10.2011 (Rasmussen L) & 1 \\
\hline \multirow[t]{7}{*}{ Italy } & \multirow[t]{4}{*}{ Northern League } & Formal: 11.05.1994-17.01.1995 (Berlusconi I) & 0 \\
\hline & & 11.06.2001-28.05.2005 (Berlusconi II) & 2 \\
\hline & & 28.05.2005-17.05.2006 (Berlusconi III) & 0 \\
\hline & & 08.05.2008-16.11.2011 (Berlusconi IV) & 1 \\
\hline & \multirow[t]{3}{*}{ National Alliance } & Formal: 11.05.1994-17.01.1995 (Berlusconi I) & 0 \\
\hline & & 11.06.2001-28.05.2005 (Berlusconi II) & 2 \\
\hline & & 28.05.2005-17.05.2006 (Berlusconi III) & 0 \\
\hline The Netherlands & List Pim Fortuyn & Formal: 21.07.2002-27.05.2003 (Balkenende I) & 0 \\
\hline \multirow[t]{3}{*}{ Norway } & \multirow[t]{3}{*}{ Progress Party } & Informal: 08.09.1985-09.05.1986 (Willoch III) & 1 \\
\hline & & 16.10.1989-03.11.1990 (Syse) & 1 \\
\hline & & 19.10.2001-17.10.2005 (Bondevik II) & 2 \\
\hline Sweden & New Democracy & Informal: 03.10.1991-06.10.1994 (Bildt) & 1 \\
\hline \multirow[t]{3}{*}{ Switzerland } & \multirow{3}{*}{$\begin{array}{l}\text { Swiss People's Party } \\
\text { (since } 1999 \text { PRRP) }\end{array}$} & Formal: 15.12.1999-10.12.2003 (Bundesrat 1999) & 2 \\
\hline & & 10.12.2003-12.12.2007 (Bundesrat 2003) & 2 \\
\hline & & 10.12.2008-14.12.2011 (Bundesrat 2008) & 1 \\
\hline
\end{tabular}

Reports only PRRPs that have attained informal or formal representation at national government level prior to 2010. While most of these cases have also been included in previous studies on the policy impact of PRRPs (De Lange, 2012; Rovny, 2013), the Syse (Norway), and Bildt (Sweden) governments might call for further explanation, as there were no official coalition agreements between the PRRPs and the government parties. Concerning Syse, Narud (1995: 10-11) explains that the centre-right coalition parties were 'dependent on the support of the Progress Party' and that the good experiences with this support paved the way for the Progress Party's inclusion in later governments. With regard to Sweden, the Bildt government 'was dependent on the New Democracy's support to pass its legislation' making this party also a 'veto player' for the reform of social policy (Anderson and Immergut, 2007: 370). Government duration is coded categorically: 0 if the government lasted less than 12 months; 1 if between 12 and 36 months; 2 if for more than 36 months.

1970-2010 (see Table 1). The sample selection is intended to cover the whole range of countries within Western Europe for the entire period since the rise of the first PRRPs. 4

${ }^{4}$ We also run all models on restricted samples focussing (1) only on the period from 1990 to 2010 and (2) only on countries with PRRPs in parliament from 1970 to 2010 . The findings of the subsample regressions very much resemble the findings of the regressions based on the entire sample of countries from 1970 to 2010. The additional models are reported in the Online Appendix (Figures C and D). 
Regarding our methodology for the quantitative part, there are often considerable doubts about the robustness of average effects in social science studies using macro variables (e.g. Kittel, 2006). This is because the regression results are very sensitive to the specification choices made and the inclusion and exclusion of specific cases (Imbens, 2015). This problem is particularly salient in our case as well. Technically speaking, the characteristics of governments where PRRPs participate are far from balanced compared with those without it: PRRP governments are not only significantly more market liberal but also tend to govern in wealthier countries which are already more liberalized, have weaker labour unions and considerably higher public debts and lower levels of unemployment. ${ }^{5}$

In order to deal with this, we use entropy balancing as an established and non-parametric way to obtain regression weights (Hainmueller and $\mathrm{Xu}, 2011$ ). This procedure assigns higher weights to observations of governments without PRRP membership that are more similar to governments with PRRPs. Put more simply, more market-liberal governments in wealthier countries with low union density and higher degrees of globalization compare closely with our governments of interest and are consequently given higher regression weights. Theoretically, these adjustments should make the estimators less dependent on specification choices, a proposition we tested with several robustness checks. ${ }^{6}$ In all models, we apply panel-corrected standard errors to avoid overconfidence (Beck and Katz, 1995).

\section{Dependent variables}

Building on the tradition of two independent dimensions of socio-economic policies - the redistribution via production of public goods and the regulation of market externalities (Lowi, 1972; Aranson and Ordeshook, 1981) we differentiate between PRRPs' impact on redistributive and regulative economic policies.

To capture the redistributive dimension of economic policies, we use changes in welfare generosity (Scruggs et al., 2014) as our dependent variable. Welfare generosity consists of the average entitlements to pensions, unemployment, and sick leave, which are calculated as the replacement rate of the (gross) average production worker wage. Welfare generosity takes into account both benefits as well as entitlement duration and qualification (see Scruggs, 2014 for detailed description) and is therefore more closely linked to the influence from political decisions than, say, social spending as a share of GDP.

In contrast to measurements of welfare efforts, the regulative dimension of economic policies is more challenging to measure. For our measure, we consider three policy fields: labour market regulation, the privatization of infrastructure, and

\footnotetext{
5 See Table B in the Online Appendix for an overview of the distributions.

${ }^{6}$ See Figure E in the Online Appendix.
} 
the regulation of financial markets. ${ }^{7}$ Labour market regulation measures the strictness of employment protection for permanent and fixed-term contracts. It consists of eight indicators (OECD, 2013). The privatization of infrastructure consists of seven indicators tapping into the regulation in energy, transport, and communications (OECD, 2011). The regulation of financial markets is captured by the index developed by Abiad and Mody (2005) covering six policy fields. The presence of an underlying regulative dimension was tested via principal component analysis and confirmed with structural equation modelling. Both procedures helped establish that the three policy areas belong to an overall regulative policy dimension. ${ }^{8}$ The latent construct obtained from the structural equation model will serve as our indicator of regulative economic policy.

For both welfare generosity and deregulation, cabinets (rather than countryyears) are the more suitable temporal and substantial units of analysis because the preferences of political parties are expected to gain effectiveness within governmental periods (see Schmitt, 2015). Hence, we use cabinets as our unit of analysis.

\section{Main independent variables: PRRPs in government}

PRRPs are expected to influence policymaking via their participation in government. Table 1 lists the parties we regard as being PRRPs, and the years and cabinets in which they have achieved formal or informal government participation. We define parties as being formal coalition partners when they are represented in the executive decision-making body, the cabinet, and support their coalition partner(s) in the legislative arena. In contrast, informal coalition partners are not represented in the executive but lend support to the coalition in the legislative arena in various forms, ranging from support for single but crucial legislative packages (e.g. adoption of the yearly budget) to systematic legislative support via sanctioned coalition agreements (see Bale and Bergman, 2006). With regard to our cases, all informal PRRP governments took the form of minority governments in which the legislative support of PRRPs was crucial for the governments' ability to pass legislation. Because of this, we see PRRPs in both formal and informal governments as being accountable in the eyes of their voters. In order to classify parties as being PRRPs, we follow the definition of Mudde (2007) and see nationalism as their core ideological feature, leading to the list of parties presented in Table 1 . However, a very similar list of PRRPs might be obtained by using alternative definitions

\footnotetext{
${ }^{7}$ While the inclusion of additional policy fields would surely be plausible, our selection is motivated by the overall importance of these three areas for national political economies as well as by the availability of quantitative data.

${ }^{8}$ The latent variable model shows an almost perfect model fit $\left(\chi^{2}=0.00^{* * *}\right.$; Comparative Fit Index (CFI) 1.0). The specific results are reported in the Online Appendix (Table A). See Figure A in the Online Appendix for the temporal development of the individual indicators.
} 
(e.g. Ignazi, 2003; Carter, 2005; Norris, 2005). In total, the list of cabinets with PRRP support includes 20 cases. $^{9}$

\section{Alternative explanations and controls}

In order to assess the impact of PRRPs on socio-economic policies, we need to make sure that differences are not due to ideological differences in their (right-wing) coalition partners. We start from the idea that these differences cannot be fully captured by party families alone. In order to analyse the potential impact of PRRPs, we therefore need measures of government positions on redistributive and regulative economic policies beyond mere party lines. To calculate these positions of each single party (including PRRPs) we use the Comparative Manifesto Project data (CMP) and follow the approach of Röth (2017) by selecting socio-economic policy issues, which can be definitely attributed either to more market-liberal or state interventionist policies. ${ }^{10} \mathrm{We}$ then calculate government positions by weighting each government party's position by its relative cabinet seat share to account for the variety of positions in coalition governments (see Döring and Manow, 2012). The resulting variable market liberalism of government has been standardized and ranges from 0 (most interventionist) to 1 (most market liberal). Please note that the CMP data does not allow us to separate between redistributive and deregulative economic issues. Thus, and if our assumptions on the different interests of PRRPs in these two policy dimensions are correct, the overall economic positions of PRRPs might appear more centrist than they deserve. While the main objective of the market-liberalism variable is to control for the ideology of PRRPs' coalition partners, this leaves the programmatic effect of PRRPs to be explained mainly by the dummy accounting for their government participation.

The ability of governments to implement reforms in line with their preferences depends on several factors. We consider that the most important of these are adequate majorities with sufficient time for the implementation of reforms. We control time through the duration of the cabinet in months and majorities with the relative cabinet share of seats in parliament.

Globalization and Europeanization are seen to be the main drivers of welfare state retrenchment and especially of economic deregulation. We control for

\footnotetext{
${ }^{9}$ However, the Schüssel II government will be analysed in combination with the Schüssel I cabinet. We proceed this way because it lasted only 1 month in 2002 and 2 in 2003. Therefore, we remain with 19 cases for the statistical analysis.

${ }^{10}$ The aggregated measure of market liberalism vs. state interventionism entails the following categories: Free enterprise (401), Incentives (402), Administrative efficiency (303), Economic orthodoxy (414), Regulation (403), Demand management (409), Economic planning (404), Controlled economy (412), Nationalization (413), Marxist analysis (415), Less spending on welfare (505), Less spending on education (507), Welfare state expansion (504), Social justice (503), Environmental protection (501), Anti-Growth (416). The issues are combined via a latent mixed item response model, using market liberalism as a latent construct and the empirical Bayesian means for the positional predictions (for a detailed discussion of the measure see Röth et al., 2016; Röth, 2017).
} 
globalization with the proportion of exports and imports to overall GDP. The influence of Europeanization is tested by an index of European Monetary Union (EMU) integration, summing up the membership levels of the three implementation stages. EMU can be seen as the most powerful instrument for restricting the fiscal and monetary autonomy of the member states, thereby curbing tendencies towards interventionist economic policies (Höpner and Schäfer, 2012).

Besides globalization and Europeanization, the so-called post-industrial context is seen as having an impact on distributive and regulative economic policies. We capture the conflicting assumptions related to the post-industrialization arguments (Iversen and Cusack, 2000) with a control consisting of the percentage of the working-age population active in the service sector. We also include union density as a control because organized labour might be a relevant opponent of both less redistributive and more market-liberal reforms.

Short- and long-term economic and demographic developments are major drivers of welfare generosity. Unemployment is an important influence on this and varies significantly in the short-run. Consequently, the lagged level and changes in unemployment are controlled for in the models. The overall affluence of a society is controlled by the chain index - the natural logarithm of real GDP per capita. In addition, we include the growth rate of GDP in order to capture economic cycles. We control for public debt by the lagged level and the change rate, as public obligations should restrict redistributive generosity and might make deregulatory policy reforms more necessary. The base and change rate of people entitled to pensions is controlled by the proportion of people older than 65 as a percentage of the population; child-related welfare demand is captured by the proportion of people younger than 15. Migration is seen as an intervening force in social spending, even though expectations in this regard are ambiguous (Soroka et al., 2015). We control for its impact by including the net migration rate in our models. Finally, each model includes lagged level dependent variables to capture the declining likelihood of further redistributive or deregulatory reforms in countries that are already liberalized to a high degree.

\section{Quantitative analysis: average effects of PRRP government participation}

We present the results of the balanced time-series cross-sectional regression models in Table 2. Overall, we estimate four models, two with welfare generosity and two with deregulation as the dependent variable. The central independent variables are PRRP government participation, the market liberalism of the respective government, and the government duration. Interpreting the effect of the PRRP dummy, note that it shows the difference of having a PRRP in government compared with market-liberal governments without PRRP participation. The PRRP dummy thus represents the distinct combination of redistributive and deregulative issues in the Radical Right's manifestos, as well as the distinct situation these parties are confronted with in terms of logrolling with their mainstream right coalition 
Table 2. Regression models for redistribution and deregulation

\begin{tabular}{|c|c|c|c|c|}
\hline \multirow{3}{*}{$\begin{array}{l}\text { Estimator } \\
\text { Dependent variables } \\
\text { Model number }\end{array}$} & \multicolumn{4}{|c|}{ Model: pcse, entropy balanced control IV's } \\
\hline & \multicolumn{2}{|c|}{$\Delta$ Generosity } & \multicolumn{2}{|c|}{$\Delta$ Deregulation } \\
\hline & (1) & $(2)$ & (3) & (4) \\
\hline Hypothesis involved & Hypothesis 1 & Hypothesis 1 & Hypothesis 2 & Hypothesis 2 \\
\hline PRRP government support & $0.59 * * *$ & $-0.52 *$ & 0.65 & $1.88 *$ \\
\hline PRRP $\times$ government duration & - & $1.09 * * *$ & - & -1.42 \\
\hline Market liberalism of government & $-2.29 * *$ & $-2.97 * *$ & $11.82 * * *$ & 7.03 \\
\hline Market liberalism $\times$ government duration & - & -0.05 & - & 5.00 \\
\hline $\begin{array}{l}\text { Government duration } \\
\text { (in months) }\end{array}$ & $-2.21 * *$ & -0.77 & $13.91 * * *$ & -1.42 \\
\hline Government seat share & $-1.28 *$ & $-1.18^{*}$ & $-7.52 * * *$ & $-7.39 * * *$ \\
\hline 1. Union density & $-1.34 * * *$ & $-1.85 * *$ & $-8.82 * * *$ & $-8.02 * * *$ \\
\hline$\Delta$ Unemployment & -0.60 & -0.95 & $29.82 * * *$ & $32.60 * * *$ \\
\hline 1. unemployment & -0.71 & -0.03 & $6.40 * *$ & 2.88 \\
\hline Deindustrialization & -1.20 & $-2.07 * *$ & 3.32 & 3.97 \\
\hline 1. Debt & 0.00 & -0.00 & $-0.03 *$ & -0.01 \\
\hline$\Delta$ Debt & 0.71 & 0.59 & $-9.02 * * *$ & $-8.41^{* *}$ \\
\hline$\Delta \mathrm{GDP}$ & 0.08 & 0.66 & $28.91 * * *$ & $33.11 * * *$ \\
\hline Ln GDP & $-2.77 *$ & $-4.46 * * *$ & 3.98 & 5.42 \\
\hline$\Delta$ Population $>65$ & -0.19 & -0.49 & $-6.22 * *$ & $-7.69 * * *$ \\
\hline$\Delta$ Population $<15$ & -1.93 & -1.23 & 6.56 & 5.60 \\
\hline 1. Level welfare generosity (models $1-2$ ) & -0.03 & -0.03 & - & - \\
\hline 1. Level deregulation (3-4) & - & - & $-9.86 * * *$ & $-8.55^{* * *}$ \\
\hline Migration rate & 1.10 & -0.28 & -3.24 & -0.28 \\
\hline 1. Globalization & $3.25 *$ & $2.88 * *$ & $-16.01 * * *$ & $-17.29 * * *$ \\
\hline$\Delta$ Globalization & -1.65 & $-2.82 * *$ & $-12.69 * * *$ & $-12.03 * * *$ \\
\hline EMU-Integration & -0.24 & 0.34 & $3.68 * * *$ & $3.30 * * *$ \\
\hline Constant & $6.75 * *$ & $10.39 * * *$ & $-12.53 * *$ & $-15.30 * *$ \\
\hline$R^{2}$ & 0.29 & 0.39 & 0.73 & 0.71 \\
\hline Number of countries & 16 & 16 & 17 & 17 \\
\hline Time frame & 1970-2010 & $1970-2010$ & 1970-2010 & 1970-2010 \\
\hline$n$ & 200 & 203 & 237 & 237 \\
\hline Positive cases & 19 & 19 & 19 & 19 \\
\hline Robustness (Online Appendix) & Figure B & Figure B & Figures $\mathrm{C}$ and D & Figures $\mathrm{C}$ and $\mathrm{D}$ \\
\hline
\end{tabular}

PRRP = Populist Radical Right Party; EMU = European Monetary Union.

All coefficients are standardized by $\beta$ weights and consequently coefficients are comparable. $\Delta$ refers to changes and 1 to lagged variables.

$*<0.90 ; * *<0.95 ; * * * 0.99$ levels of confidence.

partners. In models 2 and 4, we further analyse this average effect by interacting it with government duration.

Starting with model 1 , we compare the average impact of PRRPs on welfare generosity with other market-liberal governments - of which PRRP governments are a sub-category of. While the degree of market liberalism has a substantial and negative effect on welfare generosity $\left(-2.29^{* * *}\right)$, the average effect of PRRPs is 
positive $(+0.59 * *)$. Therefore, whereas more market-liberal government without PRRP inclusion systematically reduce the generosity of the welfare state, PRRPs curb these retrenchment efforts significantly while being members of centre-right coalitions. The balanced model shows very plausible effects on several other variables and explains a remarkable part of the variance for a first difference model $\left(R^{2}=0.29\right)$.

The difference between market-liberal governments with and without PRRP support should increase with the time a government has to implement its preferred policies. This is exactly what we find in model 2 , integrating the interaction between market liberalism and government duration. For the ease of interpretation, we graphically present the interaction effect in Figure 1, separating government duration into three categories (short if the government lasted less than 12 months; medium if between 12 and 36 months; long if for more than 36 months). In the short-run, PRRPs do not significantly matter for the generosity of benefits. However, with increasing time the differences play out very clearly. Whereas market-liberal governments pursue welfare retrenchment, governments with PRRP support defend the status quo or even slightly increase the generosity of the welfare state. The models 1 and 2 therefore give support for Hypothesis 1 .

Coming to the regulatory dimension of economic policies, model 3 shows that market-liberal governments substantially and significantly deregulate the economy $(+11.82 * *)$. While the effect of PRRP cabinet participation on deregulation is also positive, it turns out as insignificant $(+0.65$; model 4$)$. Therefore, market-liberal governments with PRRP participation are not less inclined to deregulation than market-liberal governments in general; a finding giving support for Hypothesis 2 . However, turning to the interaction of time and ideology in Figure 2, we see that this general statement on the limited impact of PRRPs on deregulation is mainly due to

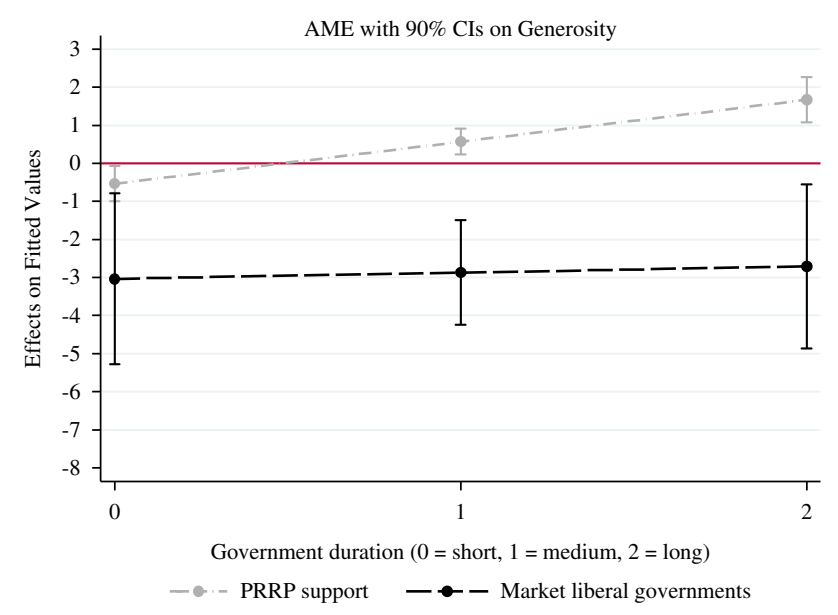

Figure 1 Average marginal effects (AME) on welfare generosity and spending conditional on government duration. PRRP $=$ Populist Radical Right Party. 


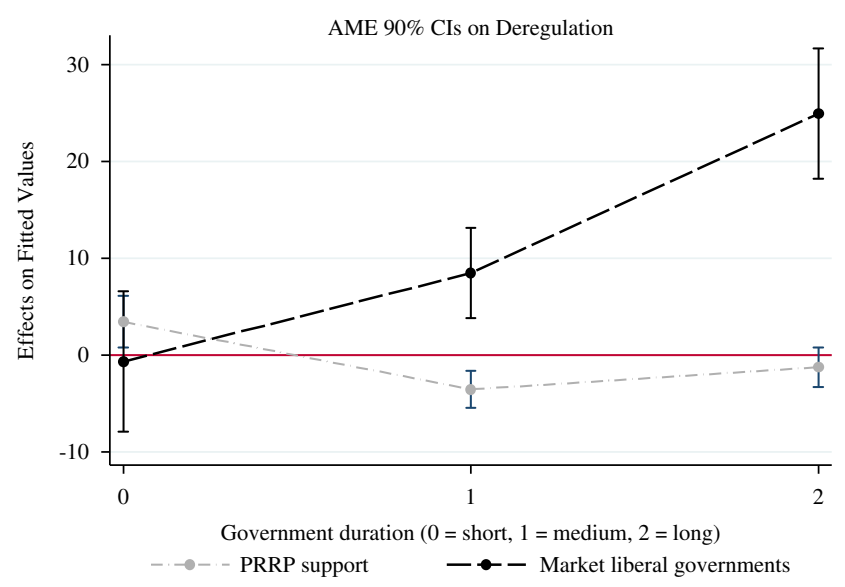

Figure 2 Average marginal effects (AME) on deregulation conditional on government duration. PRRP $=$ Populist Radical Right Party.

the shorter government duration of PRRP cabinets. While market-liberal governments without PRRPs are strong drivers of deregulation once they have sufficient time to shape their preferred policies, the impact of market-liberal governments with PRRPs is slightly positive and turns to 0 for long-term governments. Disaggregating the effect of PRRPs on the three sub-dimensions of deregulation, we observe that PRRPs seem more open to labour market deregulation and privatization than to financial market deregulation (see Online Appendix, Figure E). As the former forms of deregulation directly or indirectly affect the power of organized labour, these findings are in line with our theoretical expectations. However, for all three sub-dimensions we find that centre-right governments with PRRPs are still less inclined to deregulation than centre-right governments without PRRPs.

In sum, the quantitative analysis shows that governments with PRRP have a different impact on redistributive and regulatory economic policies than centre-right governments without PRRP support. Regarding the former, their impact on welfare generosity is in line with vote-seeking explanations. PRRPs tend to block the retrenchment agenda of their mainstream right coalition partners. Regarding deregulation, the effect of PRRPs in government is overall supportive and crucially hinges on the opportunity structure of governments. PRRPs seem to hesitantly support the deregulation agenda of their market-liberal allies, especially so in the areas of the labour market and privatization of former state-owned companies. However, market-liberal governments without PRRPs deregulate these policy areas far more.

\section{Selections for case study analysis}

The quantitative models provide evidence on the average relationship of PRRPs as government members and the resultant change in redistributive and 
regulative policies. The main aim of the following qualitative case studies is to trace how PRRPs shape formulation and implementation in redistributive and regulative policies. There are arguably multiple ways to select cases for intensive analysis drawing on quantitative analysis (Lieberman, 2005; Weller and Barnes, 2014). We follow the rationale of Weller and Barnes (2014) in proposing to use quantitative information for the selection of pathway cases: cases which have a high likelihood of allowing the observability of the mechanism (Gerring, 2007) which is theoretically expected, and whose presence is assumed by quantitative models at another level of causality.

The basic idea is not to rely on the predictive fit of a case in a quantitative model alone (as e.g. Lieberman, 2005 suggests), because a good prediction can be caused by many other variables beside the main one of interest (Rohlfing, 2008). Therefore, we select a case with good prediction and choose a second case for comparison with very similar attributes on all the important control variables. Thereby, we raise the likelihood that the observed mechanism is due to the factor we are interested in namely the presence of a PRRP in government. To ensure this similarity we apply coarsened exact matching (Iacus et al., 2012), as it allows us to select cases that vary as little as possible with respect to variables other than the one of interest. The rationale is straightforward, as coarsened exact matching provides us with comparable cases within different strata from which we select the 'most similar' ones. ${ }^{11}$

We apply this method by selecting every important variable for the model of welfare generosity as well as for the model of economic regulation. The results indicate different groups for comparison which have highly similar covariates but differ in the presence of a PRRP in government. As it turns out, multiple comparisons might be justified by the procedure, however, we prefer within-country over cross-country comparisons because we assume unobserved characteristics to be more similar in within-country analysis. ${ }^{12}$ Therefore, we choose a comparison between the Klima I (no PRRP participation) and the Schuessel I (FPÖ participation) cabinets in Austria.

Table 3 illustrates the distribution of the dependent and the most important independent variables for the two cases and shows their comparability with regard to the most important explanatory variables: the degree of programmatic market liberalism as well as the economic fundamentals hardly vary, both had exactly

\footnotetext{
11 Alternative procedures are mainly based on regression residuals or the propensity score. However, different compositions of residuals allow strongly unbalanced comparisons in principle (Rohlfing, 2008). Selections based on propensity scores avoid selection bias of the treated, but fail to balance those covariates which do not relate to the treatment variable (King et al., 2011).

12 See Tables D and E in the Online Appendix for the alternative comparisons following the matching procedure. We could have analysed the Balkenende I cabinet in the Netherlands or different Bundesrat cabinets in Switzerland. However, we decided not to choose one of them, because the Balkenende I cabinet had a very short duration and the cases in Switzerland have a much longer timespan than the ones we selected. Also, government participation in Switzerland is a problematic concept in cross-national comparisons because of the well-known 'Zauberformel', leading to the unique setting that here a PRRP is in a coalition with mainstream-left parties.
} 
Table 3. Characteristics of the selected cases

\begin{tabular}{|c|c|c|c|c|c|c|c|c|c|c|c|c|}
\hline \multirow[b]{2}{*}{$\begin{array}{l}\text { Time } \\
\text { period }\end{array}$} & \multirow[b]{2}{*}{ Country } & \multirow[b]{2}{*}{ Cabinet } & \multicolumn{3}{|c|}{ Dependent variables } & \multicolumn{6}{|c|}{ Main independent variables } & \multirow[b]{2}{*}{$\begin{array}{c}\text { Lagged } \\
\text { level } \\
\text { debt }\end{array}$} \\
\hline & & & $\begin{array}{c}\Delta \\
\text { Generosity }\end{array}$ & $\begin{array}{l}\Delta \text { Social } \\
\text { spending }\end{array}$ & $\begin{array}{c}\Delta \\
\text { Deregulation }\end{array}$ & $\begin{array}{c}\text { Market liberalism } \\
\text { of government }\end{array}$ & $\begin{array}{c}\text { Lagged } \\
\text { unemployment }\end{array}$ & $\begin{array}{c}\Delta \\
\text { Unemployment }\end{array}$ & $\begin{array}{c}\Delta \\
\text { GDP }\end{array}$ & $\begin{array}{l}\text { Lagged open } \\
\text { economy }\end{array}$ & $\begin{array}{c}\text { Government } \\
\text { duration } \\
\text { (month) }\end{array}$ & \\
\hline $1997-99$ & Austria & Klima I & -2.20 & 0.82 & 5.10 & 0.62 & 4.03 & 0.20 & 3.24 & 91.84 & 33 & 68.11 \\
\hline $2000-02$ & Austria & Schuessel I & 2.00 & 0.82 & 9.02 & 0.66 & 4.00 & -0.33 & 2.02 & 83.81 & 33 & 67.54 \\
\hline
\end{tabular}

Our calculation is based on the coarsened exact matching results. 
33 months in government, the amount of public debt is almost identical, and the lagged level of unemployment is basically the same.

\section{Qualitative analysis: Austria 1997-2003}

Our case study analysis focusses on Austria, one of the first Western European countries where a PRRP participated directly in a coalition government. In 2000, decades of power-sharing between the SPÖ (Social Democrats) and the ÖVP (Conservatives) came to an end when the Conservatives decided to form an alliance with the FPÖ, led at the time by the late Jörg Haider, giving rise to widespread international criticism. After decades of a de facto duopoly between the two mainstream parties, the FPÖ presented an interesting coalition alternative for the ÖVP to push a liberal agenda that had been systematically blocked by the SPÖ and the unions (Obinger and Tálos, 2006: 23). Here, we compare the grand coalition SPÖ-ÖVP headed by Viktor Klima that preceded the accession to power of the FPÖ with the FPÖ-ÖVP coalition headed by Wolfgang Schüssel. Our case comparison makes it possible to find some insights into the effect of PRRP participation in government. We focus on welfare reforms as measures of redistribution and privatization and the regulation of public monopolies as measures of (de-)regulation.

\section{The Klima cabinet reforms (1997-2000)}

In 1997, PM Viktor Klima (SPÖ) accessed the Austrian premiership as part of a grand coalition with the Conservative ÖVP. Klima was the Finance minister under Franz Vranitzky's previous grand coalition cabinet established after the 1995 elections, and was close to Third Way ideas. As such, he was committed to some degree of fiscal consolidation, to a moderate departure from the strongly compromiseoriented type of corporatist negotiation that characterized policymaking (Karlhofer and Tálos, 2000), and to a moderate reduction of state intervention. An important backdrop of economic reforms in that period was the peculiarly important role of the Austrian state in the economy, and the strong connections between the main political parties and the largest industries and banks. In 1989, the Austrian government was the biggest owner of listed Austrian companies, controlling 37\% of shares (Ditz, 2010: 243-244). Moreover, a large part of the industrial and banking sector was indirectly controlled by the main parties. For instance, the two largest banks, the Creditanstalt and Bank Austria, were closely connected to the Conservative ÖVP ('black') and the Social Democrats ('red'), respectively. For many experts, the large size of the state-controlled sector was considered inefficient and costly.

In many ways, economic reforms during this period were spurred by the accession of Austria to the European community and the implementation of the rules of the Single European Market. A significant movement of deregulation and opening was undertaken from the early 1990s onwards, especially in the areas 
of telecommunications. Based on a law passed in 1993, 27 privatizations were initiated (Ditz, 2010: 243-244). This movement peaked in 1998, when privatizations proceeds generated about $12 \%$ of GDP (Belke and Schneider, 2003: 18), the greatest share accounted for by Telecom privatizations.

In some areas, however, liberalization during the Klima cabinet was thwarted by the interests of the mainstream parties. For instance, even if both mainstream parties in the coalition had agreed earlier on a wide-ranging programme of the privatization of the banking sector, the actual implementation of this programme was considerably protracted because parties proved very reluctant to hand out a significant part of their economic power. In 1994, an attempt by the Swiss bank Credit Suisse to take a participation in the Creditanstalt was thwarted in the middle of coalition infighting, with parties eager to keep the bank under Austrian control. Later on, an attempt by the 'red' Bank Austria to buy the 'black' Creditanstalt created again conflict within the coalition (Berliner Zeitung, 1997), was perceived as a hostile takeover and severely undermined the trust between the coalition partners. Most importantly, this episode showed the limits of the grand coalition to pursue actual liberalization, and was presented by the FPÖ and its leader Jörg Haider as a yet another proof of the cartelization of Austrian politics and the grip of mainstream parties on the economy.

In the area of welfare, the Klima cabinet set about to implement an encompassing reform of the pension system that would significantly reduce the contribution of the federal state. This reform included a change in the mode of calculation of benefits taking into account the whole career of workers rather than the best years only, and penalties for people retiring early (Schludi, 2005: 75). The plan faced fierce resistance from the unions, which organized mass demonstrations against it (Schludi, 2005: 175-176). Interestingly, even the FPÖ was staunchly against the plan (Schludi, 2005: 169). In a context where the ruling SPÖ had strong ties with the labour unions, the government decided to involve them and negotiate concessions, but their support could not be garnered. Within the centre-right ÖVP, this led to voices demanding that the unions be side-lined altogether. However, the number of union-affiliated MPs within the social democrats gave the unions de facto veto power, thereby blocking the reform and even risked a vote of no confidence in parliament. Eventually, a very substantially watered-down version of the reform was passed and agreed with the labour unions.

Even if deadlock had been overcome, it became clear to the conservative ÖVP and its new leader Wolfgang Schüssel that substantial reforms geared towards fiscal consolidation and economic liberalization would be too difficult to pass in a coalition with the SPÖ, given their strong ties with the unions (Luther, 2010: 81). From a more party-political point of view, seeking an alliance with the FPÖ was also a way to counter the ascendency that the 'red' bloc constituted by the social democrats and unions were garnering, as shown by the takeover of the Creditanstalt. 


\section{The Schüssel cabinet reforms (2000-03)}

The 1999 Austrian federal elections yielded unexpected results: the SPÖ came first as expected with $33.2 \%$ of the vote, but Jörg Haider's anti-immigration FPÖ came second (with $26.9 \%$ ) by a few hundred votes over the ÖVP $(26.9 \%)$. While the social democrats were ready to negotiate yet another grand coalition with the ÖVP, the latter refused and eventually agreed on a government programme with the FPÖ (Obinger and Tálos, 2006, 9). In many ways, building a coalition with the FPÖ was perceived as an opportunity for the ÖVP to push through the retrenchment and deregulation measures which had been watered-down while in government with the social democrats. In this context, the ÖVP-FPÖ coalition set about implementing a drastic programme of austerity measures that would scale back a number of social programmes and public spending in general (Obinger and Tálos, 2010). The government was determined to reduce public spending to a greater extent and at a quicker pace than any of its predecessors (Ditz, 2010: 245). The FPÖ received important portfolios in this area, notably Finance and Social Affairs (Luther, 2010: 88; Ennser-Jedenastik, 2016: 415).

While the pension reform of the previous government had been substantially watered-down by the power of unions, the Schüssel government opted for sidelining them in the decision-making process, thereby breaking with a longstanding tradition of corporatist agreement in Austrian policymaking. The FPÖ did not oppose this strategy as it was in line with its longstanding hostility to union power. In this context, a major pension reform provided for an increase in the retirement age, cuts to benefits for people retiring early, a higher retirement age for public servants and a reform of widows' pensions. This reform was similar to the one passed in 1997, but its fiscal retrenchment component was to be achieved within a space of 3 years, whereas the watered-down reform of 1997 was supposed to achieve the same within 30 years (Schludi, 2005: 180). Over the two cabinets led by the ÖVP with FPÖ support, public spending as a share of GDP decreased from $51.4 \%$ in 2000 to $48.2 \%$ in 2007 (Ditz, 2010: 248).

The FPÖ had initially signed up to the retrenchment agenda of the ÖVP but afterwards significantly tempered its impetus for welfare retrenchment when it realized it severely hurt its own electorate (Heinisch, 2003). Before accessing power, the party had combined a form of 'welfare populism' advocating fiscal retrenchment at the expense of self-serving public servants and politicians on the one hand, combined with a staunch defence of acquired rights and promises of increased spending targeted at its working-class clientele on the other. Hence, the party had always opposed retrenchment for existing pensions, and defended benefits for 'deserving' recipients such as the sick, disabled, elderly, and mothers (EnnserJedenastik, 2016: 418). The party had also been keen on public spending if it served electoral purposes, as the record of Jörg Haider in government in the Land of Carinthia demonstrated. One of his flagship measures had been, for instance, the 'Kinderscheck' a monthly payment paid to mothers for each child, making the 
region the most generous for family allowances in Austria. He also initiated a 'mother's pension' allocating 150 Euros extra for 'deserving' mothers above 60, heavily subsidized gas, and other benefits targeted at pensioners in particular, often handed out in cash in front of TV cameras (Profil, 2009).

In 2002, early elections were held after the resignation of several FPÖ ministers and the collapse of the coalition. The FPÖ was severely damaged, losing 34 seats and two-thirds of its votes, and joined another coalition with the ÖVP on a much weaker basis. In 2003, after this major electoral defeat, the FPÖ sought to temper the move by the ÖVP to reform the pension system. While it had agreed on the broad agenda of a major pension reform, internal opposition within the party led the sitting social affairs Minister to ask for a referendum on the issue (Schludi, 2005: 187). After the reform was eventually agreed in cabinet, on the next day eight of the FPÖ's 18 MPs declared they would not support the bill in the plenary vote unless there were further measures to alleviate changes (Luther, 2010: 96). The party was also able to introduce a few compensation measures targeted at its own clientele. One of them was the so-called 'Hacklerregelung', which allowed older workers in specific physically demanding professions - one of its core clienteles - to retire early (Ennser-Jedenastik, 2016: 420). In this context, the party clearly sought to act as a retrenchment brake to preserve its electoral prospects.

In the areas of privatization and liberalization, where the direct costs to voters were less clear, the government pursued reforms in a fairly unrestricted manner. For instance, measures of financial liberalization passed under the Schüssel cabinet allowed for a fivefold increase in the market capitalization of the Vienna stock exchange (Ditz, 2010: 254). For the first time, the cabinet planned the total handover of ownership of a number of former state monopolies to the private sector. With a new law, they transformed the state holding agency tasked with managing state participation in industrial sectors (Österreichischen Industrieholding Aktiengesellschaft) into a privatization agency. The state totally rescinded its participation in airports, the tobacco industry, banks, and other industrial sectors, and reduced its participation in Telekom Austria and the Austrian Post (Kepplinger, 2009: 1-2). In 2001 alone, privatization proceeds reached 925 million Euros. This partly continued the movement started in the 1990s, but also accelerated in a number of domains, for instance in railways, which yielded significant resistance from the unions (Ditz, 2010: 245).

For both the ÖVP and the FPÖ, privatization was much less controversial than welfare reform because it involved lower electoral costs and even concrete strategic benefits for both parties. For the ÖVP, privatization was a way to weaken trade unions and social democrats, whose power base lay in the state monopolies. For the FPÖ, privatization was a way to dismantle the political cartel that controlled large parts of the Austrian political economy, to which they had never belonged, and perhaps place some of their officials in bureaucratic positions of influence. This strategy became explicit when the coalition adopted a new rule in 2001 to bar the representation of organizations with collective bargaining rights in the board of the Association of 
Social Security Providers, an organization hitherto governed according to the principle of self-government. This new rule was notably used to deny the chair of the Union of Railway Employees a seat on the governing board of the institution. This decision was later overturned by the Constitutional court. In the area of deregulation, the electoral trade-offs faced by the Radical Right in the area of welfare were less present, and the interests of the PRRP and the mainstream right were more aligned.

\section{Discussion and conclusion}

While previous studies of the policy impact of PRRPs have focussed almost exclusively on cultural issues, the impact of these on socio-economic policy formulation has so far largely been ignored by researchers and commentators. Our mixed methods comparative study of the impact of PRRPs on redistributive and (de-)regulative economic policies takes a first step towards filling the gap and unpacking the logic that shapes socio-economic policymaking in cabinets with and without PRRPs.

Starting with the finding that, so far, Western European PRRPs have only been able to form coalitions with market-liberal mainstream parties, our results indicate that governments with PRRP participation show less political will to retrench welfare benefits compared with other centre-right governments. In contrast, coalitions with PRRP participation show significantly more political will to deregulate - and especially to privatize - the economy, even if these efforts are not as pronounced as those of market-liberal governments without PRRP participation. Both with regard to redistributive and deregulative policies, differences between PRRP and nonPRRP governments become more visible for long-term governments with sufficient time to implement such reforms.

Based on our mixed methods design, we see two interrelated arguments for why PRRPs do allow for greater deregulation but not for greater welfare state retrenchment when participating in government. First, the working-class constituency of PRRPs makes it difficult for these parties to openly support welfare retrenchment, especially when it comes to traditional social insurance schemes benefitting their electoral clienteles, such as pensions. Second, restrained by their voters' interests, PRRPs do offer their centre-right coalition parties concessions with regard to deregulation. In the following, we would like to point to the theoretical implications of these findings for further research and also discuss how they are supported or contradicted by the quantitative and the qualitative parts of our mixed methods design.

Starting with welfare generosity, our quantitative analysis broadly supports the theoretical expectation that PRRPs will have difficulties in following a programme of retrenchment because of their rather left-leaning voter bases. The qualitative case study on Austria made it possible to nuance this view, as the FPÖ indeed supported the welfare retrenchment effort of the ÖVP, until it realized that it was damaging electorally and afterwards sought to temper the retrenchment impetus of its coalition partner. We see this as a telling example that the immigration-focussed 
Radical Right might not be aware of the electoral consequences of their socio-economic agenda - a situation that might be especially relevant for PRRPs with no former governmental experience.

With regard to deregulation, the political agendas of centre right and PRRPs find common ground, in particular where traditional structures of market regulation are dominated by labour unions. Privatization of state-owned companies and deregulation of labour markets not only constitute liberalization efforts per se, but also erode the power base of PRRP competitors such as left-wing parties. This strategy is emphasized by Jensen (2014) when he talks about the 'erode and attack' strategy pursued by right-wing governments to undermine their left competitors. In our study, the quantitative influence is shown by the positive effects of PRRPs in government on labour market deregulation and privatization. It is complemented by the case studies demonstrating similar results on another level of causality. In Austria, the Radical Right also supported privatization efforts which could undermine the power base of trade unions and social democrats.

In the long run, changing the actors that implement policies might have an even greater impact than directly changing the policies. Future research should therefore pay much more attention to these procedural changes. The arena of industrial relations seems especially promising for such analyses, as changes here might also feed back into redistributive issues. Also, focussing on the role of salience for the policy reform agenda of PRRPs could be a valuable avenue for research. In line with Culpepper (2010), it seems easier to liberalize in domains that are not very salient or technical (such as economic regulation) than in ones that are highly politicized (such as welfare issues), and our analysis is very much in line with this general statement. While such differences are surely relevant for all parties and are well documented in research on welfare state retrenchment (Pierson, 1996), salience might play an extraordinary role for the strategies of PRRPs, because it makes it more difficult to 'blur' their economic position (Afonso and Rennwald, 2017).

\section{Acknowledgements}

This article travelled a bit and along the way it received very valuable comments. The authors would like to thank three anonymous reviewers. Their careful reading and feedback improved the article significantly. Beyond the reviewers, the authors would like to thank Simon Franzmann, Mikko Kuisma, Christina Zuber, Gregor Zons, and André Kaiser for helpful suggestions. Remaining obscurities and errors are the authors' own. We would also like to thank the Fritz Thyssen Foundation for providing a travel sponsorship to one of the authors.

\section{Supplementary material}

To view supplementary material for this article, please visit https://doi.org/10.1017/ S1755773917000133 


\section{References}

Abiad, A. and A. Mody (2005), 'Financial reform: what shakes it? What shapes it?', American Economic Review 95(1): 66-88.

Afonso, A. (2015), 'Choosing whom to betray: populist right-wing parties, welfare state reforms and the trade-off between office and votes', European Political Science Review 7(2): 271-292.

Afonso, A. and Y. Papadopoulos (2015), 'How the populist radical right transformed Swiss welfare politics: from compromises to polarization', Swiss Political Science Review 21(4): 617-635.

Afonso, A. and L. Rennwald (2017), 'Social class and the changing welfare state agenda of Populist Radical Right Parties in Europe', in P. Manow and B. Palier (eds), Electoral Realignments and Welfare State Transformations in Europe, Oxford: Oxford University Press.

Aichholzer, J., S. Kritzinger, M. Wagner and E. Zeglovits (2014), 'How has radical right support transformed established political conflicts? The case of Austria', West European Politics 37(1): 113-137.

Akkerman, T. (2012), 'Comparing radical right parties in government: immigration and integration policies in nine countries (1996-2010)', West European Politics 35(3): 511-529.

Akkerman, T. and S.L. De Lange (2012), 'Radical right parties in office: incumbency records and the electoral cost of governing', Government and Opposition 47(4): 574-596.

Anderson, K.M. and E.M. Immergut (2007), 'Sweden: after social democratic hegemony', in E.M. Immergut, K.M. Anderson and I. Schulze (eds), The Handbook of West European Pension Politics, Oxford: Oxford University Press, pp. 349-395.

Aranson, P.H. and P.C. Ordeshook (1981), 'Regulation, redistribution, and public choice', Public Choice 37(1): 69-100.

Arzheimer, K. (2012), 'Working class parties 2.0? Competition between centre left and extreme right parties', in J. Rydgren (ed.), Class Politics and the Radical Right, London and New York: Routledge, pp. 75-90.

Arzheimer, K. and E.L. Carter (2003), 'Explaining variation in the extreme right vote: the individual and the political environment'. Keele European Parties Research Unit Working Paper No. 19, Keele University, Keele.

Arzheimer, K. and E.L. Carter (2009), 'Christian religiosity and voting for West European radical right parties', West European Politics 32(5): 985-1011.

Bale, T. (2003), 'Cinderella and her ugly sisters: the mainstream and extreme right in Europe's bipolarising party systems', West European Politics 26(3): 67-90.

Bale, T. (2008), 'Turning round the telescope. centre-right parties and immigration and integration policy in Europe 1', Journal of European Public Policy 15(3): 315-330.

Bale, T. and T. Bergman (2006), 'Captives no longer, but servants still? Contract parliamentarism and the new minority governance in Sweden and New Zealand', Government and Opposition 41(3): 422-449.

Beck, N. and J.N. Katz (1995), 'What to do (and not to do) with time-series cross-section data', American Political Science Review 89(3): 634-647.

Belke, A. and F. Schneider (2003), 'Privatization in Austria: some theoretical reasons and performance measures'. CESifo Conference, November 1-2, 2003, CESifo, Villa La Collina, Cadenabbia, Italy.

Berliner Zeitung (1997), 'Österreichs Regierungsparteien streiten wegen der Privatisierung der "Creditanstalt" Koalitionskrise in Wien', January 10. Retrieved 29 May 2017 from http:/www.berliner-zeitung.de/ 16443936

Betz, H.-G. (1994), Radical Right-Wing Populism in Western Europe, New York: St. Martin's Press.

Betz, H.-G. (2002), 'Conditions favoring the success and failure of radical right-wing populist parties in contemporary democracies', in Y. Mény and Y. Surel (eds), Democracies and the Populist Challenge, Houndmills: Palgrave, pp. 197-213.

Betz, H.-G. and C. Johnson (2004), 'Against the current - stemming the tide: the nostalgic ideology of the contemporary radical populist right', Journal of Political Ideologies 9(3): 311-327. 
Carter, E. (2005), The Extreme Right in Western Europe: Success or Failure?, Manchester: Manchester University Press.

Cole, A. (2005), 'Old right or new right? The ideological positioning of parties of the far right', European Journal of Political Research 44(2): 203-230.

Culpepper, P.D. (2010), Quiet Politics: Business Power and Corporate Control in Europe and Japan, Cambridge: Cambridge University Press.

Davidsson, J.B. and P. Emmenegger (2013), 'Defending the organisation, not the members: unions and the reform of job security legislation in Western Europe', European Journal of Political Research 52(3): 339-363.

De Lange, S.L. (2007), 'A new winning formula? The programmatic appeal of the radical right', Party Politics 13(4): 411-435.

De Lange, S.L. (2008), 'From pariah to power: the government participation of radical right-wing populist parties in West European democracies'. Doctoral dissertation, University of Antwerp, Antwerp, Belgium.

De Lange, S.L. (2012), 'New alliances: why mainstream parties govern with radical right-wing populist parties', Political Studies 60(4): 899-918.

Ditz, J. (2010), 'Economic policies and economic change', in G. Bischof and F. Plasser (eds), The Schüssel Era in Austria, New Orleans, LA: University of New Orleans Press, pp. 235-261.

Döring, H. and P. Manow (2012), 'Parliament and Government Composition Database (ParlGov): an infrastructure for empirical information on parties, elections and governments in modern democracies', Version 12/10-15 October 2012. Retrieved 10 November 2015 from http://www. parlgov.org/static/static-2014/stable/index.html

Ennser-Jedenastik, L. (2016), 'A welfare state for whom? A group-based account of the Austrian Freedom Party's social policy profile', Swiss Political Science Review 22(3): 409-427.

Gabel, M.J. and J.D. Huber (2000), 'Putting parties in their place: inferring party left-right ideological positions from party manifestos data', American Journal of Political Science 44(1): 94-103.

Gerring, J. (2007), Case Study Research: Principles and Practices, Cambridge: Cambridge University Press.

Giger, N. and M. Nelson (2011), 'The electoral consequences of welfare state retrenchment: blame avoidance or credit claiming in the era of permanent austerity?', European Journal of Political Research 50(1): 1-23.

Hainmueller, J. and Y. Xu (2011), 'Ebalance: a stata package for entropy balancing', Journal of Statistical Software 54(7): 1-18.

Häusermann, S., G. Picot and D. Geering (2013), 'Rethinking party politics and the welfare state - recent advances in the literature', British Journal of Political Science 43(1): 221-240.

Heinisch, R. (2003), 'Success in opposition - failure in government: explaining the performance of rightwing populist parties in public office', West European Politics 26(3): 91-130.

Höpner, M. and A. Schäfer (2012), 'Integration among unequals. How the heterogeneity of European varieties of capitalism shapes the social and democratic potential of the EU', MPIfG Discussion Paper No. 12/5. Max Planck Institute for the Study of Societies, Cologne, Germany.

Iacus, S.M., G. King and G. Porro (2012), 'Causal inference without balance checking: coarsened exact matching', Political Analysis 20(4): 1-24.

Ignazi, P. (2003), Extreme Right Parties in Western Europe, New York: Oxford University Press.

Imbens, G. (2015), 'Matching methods in practice: three examples', Journal of Human Resources 50(2): 373-419.

Ivarsflaten, E. (2005), 'The vulnerable populist right parties: no economic realignment fuelling their electoral success', European Journal of Political Research 44(3): 465-492.

Iversen, T. and T.R. Cusack (2000), 'The causes of welfare state expansion: deindustrialization or globalization?', World Politics 52(3): 313-349.

Jensen, C. (2014), The Right and the Welfare State, Oxford: Oxford University Press.

Karlhofer, F. and E. Tálos (2000), 'Sozialpartnerschaft unter Druck: Trends und Szenarien', in A. Pelinka, F. Plasser and W. Meixner (eds), Die Zukunft der Österreichischen Demokratie: Trends, Prognosen und Szenarien, Vienna: Signum, pp. 381-402.

Kepplinger, J. (2009), Privatisierungen unter ÖVP-FPÖ/BZÖ., Linz: Landesrat Oberösterreich. 
King, G., R. Nielsen, C. Coberley, J.E. Pope and A. Wells (2011), 'Comparative effectiveness of matching methods for causal inference'. Unpublished manuscript. Retrieved 10 November 2015 from http:// gking.harvard.edu/files/ psparadox.pdf

Kitschelt, H. (1995), The Radical Right in Western Europe: A Comparative Analysis, Ann Arbor, MI: The University of Michigan Press.

Kitschelt, H. (2004), Diversification and Reconfiguration of Party Systems in Postindustrial Democracies (Europäische Politik (03/2004)), Bonn: International Policy Analysis Unit, FriedrichEbert-Foundation.

Kitschelt, H. (2007), 'Growth and persistence of the radical right in postindustrial democracies: advances and challenges in comparative research', West European Politics 30(5): 1176-1206.

Kittel, B. (2006), 'A crazy methodology? On the limits of macro-quantitative social science research', International Sociology 21(5): 647-677.

Kriesi, H., E. Grande, R. Lachat, M. Dolezal, S. Bornschier and T. Frey (2006), 'Globalization and the transformation of the national political space: six European countries compared', European Journal of Political Research 45(6): 921-956.

Lieberman, E.S. (2005), 'Nested analysis as a mixed-method strategy for comparative research', American Political Science Review 99(3): 435-452.

Lowi, T.J. (1972), 'Four systems of policy, politics, and choice', Public Administration Review 32(4): 298-310.

Luther, K.R. (2010), 'Governing with right-wing populists and managing the consequences: Schüssel and the FPÖ', in G. Bischof and F. Plasser (eds), The Schüssel Era in Austria, Innsbruck: Innsbruck University Press, pp. 79-103.

McGann, A. and H. Kitschelt (2005), 'The radical right in the Alps: evolution of support for the Swiss SVP and Austrian FPÖ', Party Politics 11(2): 147-171.

Minkenberg, M. (2001), 'The radical right in public office: agenda-setting and policy effects', West European Politics 24(4): 1-21.

Mudde, C. (2007), Populist Radical Right Parties in Europe, Cambridge: Cambridge University Press.

Mudde, C. (2013), 'Three decades of Populist Radical Right Parties in Western Europe: so what?', European Journal of Political Research 52(1): 1-19.

Narud, H.M. (1995), 'Coalition termination in Norway: models and cases', Scandinavian Political Studies 18(1): 1-24.

Norris, P. (2005), Radical Right: Voters and Parties in the Electoral Market, New York: Cambridge University Press.

Obinger, H. and E. Tálos (2006), Sozialstaat Österreich zwischen Kontinuität und Umbau. Eine Bilanz der ÖVP/FPÖ/BZÖ-Koalition, Wiesbaden: VS Verlag für Sozialwissenschaften.

Obinger, H. and E. Tálos (2010), 'Janus-faced developments in a prototypical Bismarckian welfare state. Welfare reforms in Austria since the 1970s', in Bruno Palier (eds), A Long Goodbye to Bismarck? The Politics of Welfare Reform in Continental Europe, Amsterdam: Amsterdam University Press, pp. 101-128.

Obinger, H., C. Schmitt and R. Zohlnhöfer (2014), 'Partisan politics and privatization in OECD countries', Comparative Political Studies 47(9): 1294-1323.

OECD (2011), 'Product market regulation database'. Retrieved 10 November 2015 from http://www.oecd. org/economy/pmr/

OECD (2013), 'OECD indicators of employment protection', Annual time series data 1985-2013. Retrieved 10 November 2015 from http://www.oecd.org/employment/emp/oecdindicatorsof employmentprotection.htm

Pierson, P. (1996), 'The new politics of the welfare state', World Politics 48(2): 143-179.

Profil (2009), 'Kärnten-Pleite: Haiders Vorzeigeland steht vor dem Finanzkollaps'. December 5. Retrieved 29 May 2017 from https:/www.profil.at/home/kaernten-pleite-haiders-vorzeigeland-finanzkollaps257104

Rohlfing, I. (2008), 'What you see and what you get: pitfalls and principles of nested analysis in comparative research', Comparative Political Studies 41(11): 1492-1514. 
Röth, L. (2017), 'Equivalence presupposes validity. Toward comparable party positions on the market dimension'. Paper prepared for EPSA Conference 2017, June 22-24, Milan.

Röth, L., A. Kaiser, Ç. Varol and U. Sadioğlu (2016), 'Centre-periphery conflict and ideological distance in Turkey', Swiss Political Science Review 22(4): 585-607.

Rovny, J. (2013), 'Where do radical right parties stand? Position blurring in multidimensional competition', European Political Science Review 5(1): 1-26.

Schludi, M. (2005), The Reform of Bismarckian Pension Systems, Amsterdam: Amsterdam University Press.

Schmitt, C. (2015), 'Panel data analysis and partisan variables: how periodization does influence partisan effects', Journal of European Public Policy 23(10): 1442-1459.

Schumacher, G. and K.v. Kersbergen (2014), 'Do mainstream parties adapt to the welfare chauvinism of populist parties?', Party Politics 22(3): 300-312.

Scruggs, L. (2014), 'Social welfare generosity scores in CWED 2: a methodological genealogy'. CWED Working Paper No. 01, Storrs, CT February.

Scruggs, L., D. Jahn and K. Kuitto (2014), 'Comparative welfare entitlements dataset 2', Version 2014-03. University of Connecticut and University of Greifswald. Retrieved 10 November 2015 from http:// cwed2.org/

Soroka, S.N., R. Johnston, A. Kevins, K. Banting and W. Kymlicka (2016), 'Migration and welfare state spending', European Political Science Review 8(2): 173-194.

Spies, D.C. (2013), 'Explaining working-class support for extreme right parties: a party competition approach', Acta Politica 48(3): 296-325.

Spies, D.C. and S. Franzmann (2011), 'A two-dimensional approach on the political opportunity structure of extreme right parties in Western Europe', West European Politics 34(5): 1044-1069.

Van der Brug, W. and M. Fennema (2003), 'Protest or mainstream? How the European anti-immigrant parties develop into two separate groups by 1999', European Journal of Political Research 42(1): $55-76$.

Van der Brug, W. and M. Fennema (2007), 'What causes people to vote for a radical-right party? A review of recent work', International Journal of Public Opinion Research 19(4): 474-487.

Van der Brug, W. and J. Van Spanje (2009), 'Immigration, Europe and the "new" cultural dimension', European Journal of Political Research 48(1): 309-334.

Van Spanje, J. and W. Van der Brug (2007), 'The party as pariah: the exclusion of anti-immigrant parties and its effect on their ideological positions', West European Politics 30(5): 1022-1040.

Verbeek, B. and A. Zaslove (2015), 'The impact of Populist Radical Right Parties on foreign policy: the northern league as a junior coalition partner in the Berlusconi governments', European Political Science Review 7(4): 525-546.

Weller, N. and J. Barnes (2014), Finding Pathways: Mixed-Method Research for Studying Causal Mechanisms, Cambridge: Cambridge University Press.

Zaslove, A. (2004), 'Closing the door? The ideology and impact of radical right populism on immigration policy in Austria and Italy', Journal of Political Ideologies 9(1): 99-118. 